Int. J. Dev. Biol. 50: 627-635 (2006)

doi: $10.1387 / \mathrm{ijdb} .052130 \mathrm{ew}$

Original Article

\title{
Selection of reference genes in mouse embryos and in differentiating human and mouse ES cells
}

\author{
ERIK WILLEMS ${ }^{1}$, ILEANA MATEIZEL ${ }^{2}$, CAROLINE KEMP ${ }^{1}$, GREET CAUFFMAN ${ }^{2}$, KAREN SERMON ${ }^{2}$ \\ and LUC LEYNS*,1 \\ ${ }^{1}$ Lab for Cell Genetics, Vrije Universiteit Brussel (VUB) and ${ }^{2}$ Research Center for Reproduction and Genetics, University Hospital and \\ Medical School of the Vrije Universiteit Brussel (AZ-VUB), Brussels, Belgium
}

\begin{abstract}
Embryonic Stem (ES) cells have the potential to form every cell of the body and thus are of great promise for tissue transplantation. One of the rising techniques that allows studying the differentiation state of ES cells is quantitative RT-PCR (qRT-PCR). When relative quantification by qRT-PCR is applied, accurate normalization is necessary, since differentiated embryonic stem cells and developing embryos contain heterogeneous cell populations. Corrections for variations in the qRT-PCR reaction are needed to allow comparisons between different samples. We applied the normalization tools $\mathrm{geNorm}$ and Normfinder to ten reference genes identifying the most stable ones for relative quantification of gene expression during differentiation of human ES cells, as well as in differentiated mouse ES cells and in the developing mouse embryo. For relative quantification by qRT-PCR in these systems, we advise to use normalization factors based on multiple stable reference genes. However, when the use of several reference genes would be unpractical, a single reference gene in each experimental setup could be sufficient. When looking for single stable reference genes, beta-actin works best in both mouse embryo and ES cell experiments and glyceraldehyde-3-phosphate-dehydrogenase can be applied in both mouse and human ES cell experiments.
\end{abstract}

KEY WORDS: embryonic stem cell, embryo, quantitative RT-PCR, reference gene

\section{Introduction}

Embryonic stem (ES) cells have been derived for several mammals from the inner cell mass (ICM) of a preimplantation blastocyst (Evans and Kaufman, 1981; Thomson et al., 1998). These cells have the property to divide unlimitedly and remain undifferentiated in vitro, a process controlled by factors such as NANOG and OCT4 (or POU5F1) (Niwa et al., 2000; Chambers et al., 2003). In specific culture conditions they are able to differentiate into any cell type of the adult body. These features make ES cells a potential alternative for organ transplantation. It has been shown in human as well as mouse ES cells that Retinoic Acid (RA) specifically induces neuronal cells and dimethylsulfoxide (DMSO) has been shown to induce different mesoderm derived cell types like skeletal and cardiac muscle (Maltsev et al., 1993; Bain et al., 1996). More recently, growth factors expressed in the developing embryo have been successfully applied to mouse and human ES cells to obtain specified cell types indicating a need for drawing parallels between the developing embryo and ES cell differentiation (Schuldiner et al., 2000; Kubo et al., 2004).
During the differentiation of ES cells or the development of the embryo, the expression of numerous genes is altered, reflected in the mRNA transcription of these genes. At present, the most widely applied technique to detect and quantify mRNA levels is quantitative Reverse Transcription PCR (qRT-PCR) (Bustin, 2002). However, there are several technical steps during a qRT-PCR experiment that may show variation between genes and samples, such as the reverse transcription and the GPCR reaction itself (Pfaffl, 2001; Ramakers et al., 2003; Stahlberg et al., 2004). Accurate corrections or normalizations of qRT-PCR results are thus essential to allow precise comparisons between samples.

The most applied approach for normalization is the use of reference genes also known as housekeeping genes (Bustin,

\footnotetext{
Abbreviations used in this paper: actb, beta-actin; $\mathrm{b} 2 \mathrm{~m}$, beta-2-microglobulin; GAPDH, glyceraldehyde-3-phosphate dehydrogenase; hES, human embryonic stem (cell); ICM, inner cell mass; mES, mouse embryonic stem (cell); NF, normalization factor; qRT-PCR, quantitative reverse-transcription polymerase chain reaction; RA, retinoic acid; TBP, TATA box binding protein.
} 
2002). These genes should have similar mRNA levels in all samples analyzed and they should not be regulated by the experimental treatment or condition used. Many genes have been described and used as reference genes such as glyceraldehyde3-phosphate dehydrogenase (GAPDH), beta-actin (ACTB), hypoxanthine phosphoribosyltransferase (HPRT1) and ribosomal RNA 18S (18S). However, most of these "classic" reference genes do not always meet the requirements described above (Schmittgen and Zakrajsek, 2000; Goidin et al., 2001; Bustin, 2002; Murphy and Polak, 2002; de Kok et al., 2005).

Vandesompele et al. (2002) suggested that not one, but multiple reference genes should be used for accurate normalization. Their normalization strategy is based on the geometric averaging of the expression level of multiple reference genes, allowing for a ranking of the reference genes according to their stability and of which a normalization factor (NF) can be derived for each sample with the "geNorm" tool. A similar approach using geometric averaging has been described by Pfaffl et al. (2004) and two other studies described the use of mixed linear effect modeling to rank a selection of reference genes (Andersen et al., 2004; Szabo et al., 2004). Andersen et al. (2004) have designed "Normfinder" a Microsoft Excel add-in that ranks reference genes based on the mixed linear effect modeling statistical approach.

In summary, in every experimental setup, an extensive search to identify one or more suitable reference gene(s) is needed, of which the most stable one(s) should be used. In addition to the arguments described above, an accurate normalization is necessary in developmental biology since during the differentiation of ES cells and the development of the embryo, cell types change rapidly and the cell population becomes more and more heterogeneous.

In order to be able to study gene expression in these systems by relative quantification with qRT-PCR, we have applied geNorm (Vandesompele et al., 2002) and Normfinder (Andersen et al., 2004) to ten commonly used reference genes to identify the most stable genes in two spontaneously differentiated human ES (hES) cell lines. Additionally, the stability of reference genes was studied in mouse ES (mES) cells and the developing mouse embryo.

We have identified several stable reference genes in each of the systems studied. Based on our results, we advise to use normalization factors based on multiple stable reference genes. However, a single reference gene could be sufficient for each system if the use of multiple reference genes is unpractical, betaactin works in both mouse embryo and ES cell experiments and glyceraldehyde-3-phosphate-dehydrogenase can be applied in both mouse and human ES cell experiments, but this approach is less accurate than using multiple reference genes and their derived normalization factors.

\section{Results}

To identify suitable reference genes for three related experimental systems (I) differentiating hES cells, (II) differentiating mES cells and (III) the developing mouse embryo, a set of ten commonly used reference genes was selected for both human and mouse: ribosomal RNA 18S (18S), glyceraldehyde-3-phosphate dehydrogenase (GAPDH), beta-actin (ACTB), hypoxanthine phosphoribosyltransferase (HPRT1), phosphoglycerate ki-

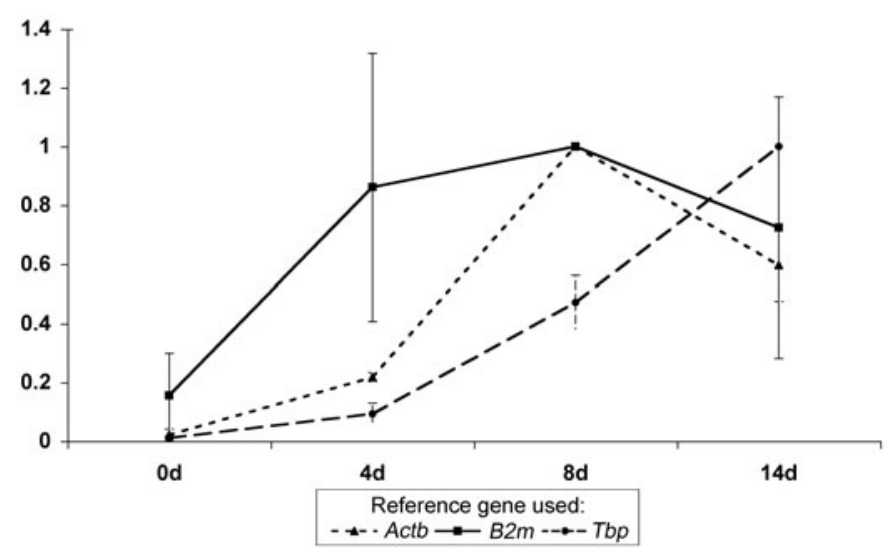

Fig. 1. Expression of Mash1 during neural differentiation of $\mathrm{mES}$ cells with RA. Samples were taken at day 0 (mES cells), 4, 8 and 14. Expression levels were corrected for beta-actin (Actb, solid line, triangles), beta-2-microglobulin (B2m, dashed line, squares) and TATA box binding protein (Tbp, dashed line, circles) and were made relative to the sample with highest expression (value of one). Error bars represent the standard deviation of three independent experiments.

nase-1 (PGK1), ubiquitin C (UBC), TATA box binding protein (TBP), beta-2-microglobulin (B2M), glucose-6-phosphate dehydrogenase (G6PD) and lactate dehydrogenase A (LDHA).

A qRT-PCR approach linked to two available statistical analysis tools (geNorm and Normfinder), that apply different statistical models, was used to determine the stability of the reference genes tested (Supplementary Table B contains the stability values which were used to rank the reference genes).

\section{Reference genes in differentiating hES cells}

Since hES cells have a therapeutic potential, accurate analysis tools are required to follow their differentiation, including qRTPCR with stable reference genes. Human ES cell aggregates were allowed to form EB, which were differentiated spontaneously in the presence of FCS. Days of collection were selected based on the appearance of beating structures around day 12 together with the expression of cardiac myosin (data not shown).

To limit biological variability, data points from two independent hES cell lines, VUB01 and VUB02, were combined to analyze reference gene expression stability with geNorm and Normfinder (Table I) (Mateizel et al., 2005). 18S, GAPDH and UBC were located in the top three of most stable genes, whereas ACTB, HPRT1 and B2M were found in the bottom of the stability ranking.

When considering the two cell lines separately for biological differences (data not shown), most reference genes were found at similar positions in the ranking. However, PGK1 and TBP showed significant difference in their ranking between both hES cell lines tested. TBP was stable in VUB01 (ranked first), but not in VUB02 (ranked ninth). On the contrary, PGK1 was stable in VUB02 (ranked first) and not in VUB01 (ranked fifth). However, GAPDH and UBC were stable in both cell lines separately.

\section{Reference genes in differentiating mES cells}

As the mouse represents a model for the human, the study on the stability of reference genes was also performed on differentiating $\mathrm{mES}$ cells in order to compare the reference gene stability 
TABLE 1

RANKING OF TEN SELECTED REFERENCE GENES IN ES CELLS AND EMBRYO

\begin{tabular}{|c|c|c|c|c|c|c|c|c|}
\hline \multirow[b]{2}{*}{ Rank } & \multicolumn{2}{|c|}{ Mouse Embryo } & \multicolumn{2}{|c|}{$\begin{array}{c}\text { mES/DMSO: } \\
\text { Mesodermal Differentiation }\end{array}$} & \multicolumn{2}{|c|}{$\begin{array}{c}\text { mES/RA: } \\
\text { Neuronal Differentiation }\end{array}$} & \multicolumn{2}{|c|}{$\begin{array}{c}\text { hES: } \\
\text { Spontaneous Differentiation }\end{array}$} \\
\hline & Normfinder & geNorm & Normfinder & geNorm & Normfinder & geNorm & Normfinder & geNorm \\
\hline 1 & Tbp & Tbp & Gapdh & Gapdh & Actb & Actb & UBC & UBC \\
\hline 2 & G6pd & Actb & Actb & Tbp & Pgk1 & Pgk1 & PGK1 & GAPDH \\
\hline 3 & Actb & G6pd & Pgk1 & Pgk1 & Gapdh & Gapdh & $18 S$ & $18 \mathrm{~S}$ \\
\hline 4 & Ubc & Ubc & Tbp & Actb & $18 S$ & Tbp & GAPDH & PGK1 \\
\hline 5 & Gapdh & Gapdh & $18 S$ & $18 \mathrm{~S}$ & Tbp & $18 S$ & G6PD & G6PD \\
\hline 6 & $18 \mathrm{~S}$ & $18 \mathrm{~S}$ & G6pd & G6pd & G6pd & G6pd & TBP & TBP \\
\hline 7 & $\mathrm{~B} 2 \mathrm{~m}$ & $\mathrm{~B} 2 \mathrm{~m}$ & Ldha & Ldha & Hprt1 & Hprt1 & LDHA & LDHA \\
\hline 8 & Pgk1 & Pgk1 & Hprt1 & Hprt1 & Ubc & Ldha & HPRT1 & HPRT1 \\
\hline 9 & Hprt1 & Hprt1 & Ubc & Ubc & Ldha & Ubc & АСТВ & АСТВ \\
\hline 10 & Ldha & Ldha & $\mathrm{B} 2 \mathrm{~m}$ & $\mathrm{~B} 2 \mathrm{~m}$ & $\mathrm{~B} 2 \mathrm{~m}$ & $\mathrm{~B} 2 \mathrm{~m}$ & B2M & $\mathrm{B} 2 \mathrm{M}$ \\
\hline
\end{tabular}

Ten reference genes were ranked based on their stability value calculated by geNorm and Normfinder (stability values are available in Supplementary Table B). The stability of reference genes was studied in the developing mouse embryo, in mouse ES cells differentiated to mesoderm with Dimethylsulfoxide (DMSO), in mouse ES cells differentiated to neuroectoderm with retinoic acid (RA) and in human ES cells spontaneously differentiated in the presence of fetal calf serum (FCS).

in both mammalian systems.

Differentiation into mesoderm was triggered by adding $1 \%$ DMSO to EB whereas neuronal cells were induced by adding $10^{-6} \mathrm{M}$ RA. EB were collected at three time points: at four days, since gastrulation specific genes are active in EB at that time as assessed by expression of Brachyury and Goosecoid (data not shown, Fehling et al. (2003) and Tada et al. (2005)); at eight days, because spontaneous beating can be observed together with expression of cardiac myosin after DMSO treatment (data not shown) and the expression of Mash1, a marker of preneural cells, is detected after RA treatment (Fig. 1) and after fourteen days, since high numbers of neurons are present after RA treatment (Bain et al., 1996).

During differentiation of $\mathrm{mES}$ cells into mesodermal derivatives, the reference genes that were to be found in the top of the stability ranking are Gapdh, Actb and Pgk1, of which Actb is the only one also stable in the mouse embryo (Table I). In contrast to the mouse embryonic development system (see below), several genes of the glycolytic pathway are ranked in the top of the list (Gapdh and Pgk1). Similar results are seen when treating mES cells with RA, with Actb as the most stable reference gene (Table I). Importantly, no significant differences were found in ranking and stability of the reference genes between samples treated with RA or DMSO. Since spontaneous differentiated EB might contain more heterogeneous cell populations in comparison to RA and DMSO differentiated EB, we have compared spontaneous differentiation with mesodermal and neuronal differentiation, but no significant difference in ranking or stability values of the reference genes was found (data not shown).

To demonstrate the necessity of analyzing and selecting the best reference gene(s), the expression of the pre-neural marker Mash1 was followed during RA-induced differentiation after correction for different reference genes (Fig. 1). Significant differences can be seen when using stable (Actb), less stable (Tbp) or unstable $(\mathrm{B} 2 \mathrm{~m})$ reference genes.

\section{Reference genes in the developing embryo}

Since many parallels between the mouse embryo and differentiating ES cells can be drawn, reference gene stability was also studied in the mouse embryo. Different stages of embryonic development were used: blastocysts ( 3.5 days post coitum (dpc)) were selected since ES cells can be derived from them, $7.5 \mathrm{dpc}$ embryos are gastrulating and neurulating, $9.5 \mathrm{dpc}$ embryos start to form several organs and $11.5 \mathrm{dpc}$ embryos already contain mature cell types.

Reverse transcription reactions of a total RNA pool obtained from multiple embryos collected from different mice (to take biological variation into account) were used to study the expression of reference genes, which were ranked according to their stability (Table I). Tbp, Actb and G6pd were in the top three (most stable) of the ranking during the developing embryonic stages studied. Hprt1 and 18S were found in the bottom part of the list.

Most of the genes of the glycolytic pathway (Gapdh, Ldha, Pgk1) are ranked in the lower half of the stability list. To investigate this further, the expression of the reference genes studied in the embryo was corrected with a stable reference gene (Fig. 2, corrected for Actb). Lower levels of mRNA were found in the blastocyst for the reference genes involved in sugar metabolism, namely Gapdh, Ldha and Pgk1. Figure 2 also shows that Hprt1 is substantially downregulated from preimplantation to postimplantation development.

To demonstrate the importance of using an appropriate reference gene, the expression of two markers for undifferentiated cells, Oct4 (or Pou5f1) and Nanog, was compared in mES cells and mouse blastocysts (Niwa et al., 2000; Smith, 2001; Chambers et al., 2003). In Table II, the difference in relative expression of Nanog and Oct4 between mouse blastocysts and $\mathrm{mES}$ cells using several reference genes is shown. Depending on the reference gene used, the expression of both Nanog and

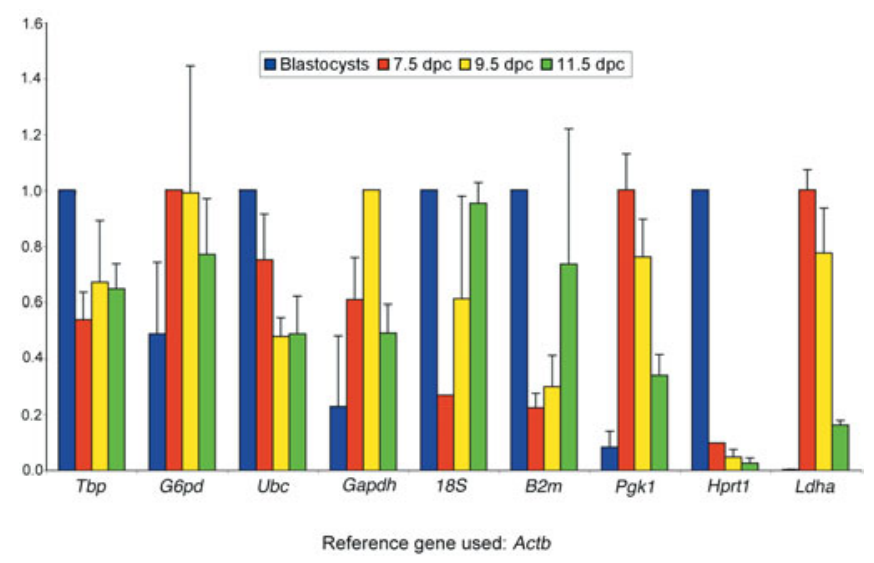

Fig. 2. Relative expression of the studied reference genes in the developing mouse embryo (blastocysts or $3.5 \mathrm{dpc}, 7.5 \mathrm{dpc}, 9.5 \mathrm{dpc}$ and $11.5 \mathrm{dpc}$ ) corrected for beta-actin (Actb), one of the stable genes. For each gene, expression was made relative to the sample with the highest expression (value of one). Error bars represent the standard deviation of three independent reverse transcriptions from an RNA pool. 
Oct4 is higher in blastocysts (corrected for Gapdh) or mES cells (corrected for Hprt1) or have comparable expression in both samples (corrected for Actb).

\section{Discussion}

\section{Determining stable reference genes}

The importance of reference genes and the need to validate them for each experimental system has already been stressed in several publications (Bustin, 2002; Vandesompele et al., 2002). Different approaches to identify the best reference gene have been described, ranging from using classic PCR coupled to gel electrophoresis (Goidin et al., 2001), Northern Blot (Solanas et al., 2001) and more recently microarrays (Hoerndli et al., 2004) and qRT-PCR. The latter technique is probably the most powerful to address the issue of reference gene analysis, since it allows a more sensitive quantification compared to the other techniques described (Bustin, 2002). Several qRT-PCR approaches for normalization have been developed such as the use of absolute quantification (Tricarico et al., 2002), relative quantification (Schmittgen and Zakrajsek, 2000), the use of RiboGreen (Hashimoto et al., 2004) and more recently the use of statistical models (Vandesompele et al., 2002; Andersen et al., 2004; Pfaffl et al., 2004; Szabo et al., 2004; de Kok et al., 2005).

Since our aim is to develop a sensitive relative quantification of the expression levels of genes between different samples (here embryos and differentiating ES cells), a qRT-PCR approach was selected in combination with the statistical tools, geNorm and Normfinder, allowing assumption free analysis of reference genes. We also attempted to identify single reference genes that could be used to analyze results from the mouse embryo, mES cells and hES cells, since the method of single reference genes is still widely applied.

No large differences (except for a few occasional shifts of one or two positions in the obtained rankings) between geNorm and Normfinder were observed as illustrated in Table I. In support to what we found, Szabo et al. (2004) have shown that the modelbased approach is very similar to the geometric averaging approach. Andersen et al. (2004) have mentioned that Normfinder is less sensitive to co-regulated reference genes than geNorm. We have investigated whether coregulation affects the outcome of our results with the co-regulated genes GAPDH and PGK1. When removing one of them out of the analysis, we could not see any difference in the result, showing that in our data co-regulation

\section{TABLE 2}

\section{EXPRESSION OF OCT4 AND NANOG IN MOUSE ES CELLS AND BLASTOCYSTS}

\begin{tabular}{ccccc} 
& \multicolumn{2}{c}{ Oct4 Expression } & \multicolumn{2}{c}{ Nanog Expression } \\
$\begin{array}{c}\text { Reference } \\
\text { gene }\end{array}$ & ES cells & Blastocysts & ES cells & Blastocysts \\
\hline Actb & 1.00 & $0.98 \pm 0.05$ & 1.00 & $0.99 \pm 0.10$ \\
Gapdh & $0.28 \pm 0.10$ & 1.00 & $0.25 \pm 0.08$ & 1.00 \\
Hprt1 & 1.00 & $0.38 \pm 0.08$ & 1.00 & $0.57 \pm 0.16$ \\
\hline
\end{tabular}

Expression of Oct4 and Nanog was corrected for beta-actin (Actb, a stable reference gene), glyceraldehyde-3-phosphate dehydrogenase (Gapdh) and hypoxanthine phosphoribosyltransferase (Hprt1), both of which are commonly used reference genes). For each gene, the expression was made relative to the sample with the highest expression (value of one). The standard error of three independent reverse transcriptions from pooled samples is indicated (average expression \pm standard error). does not affect the ranking of reference genes by stability.

Therefore, because of their similarity, the distinction between geNorm and Normfinder will not be considered further.

\section{Reference genes in hES cells, in mES cells and in the developing embryo}

Since $\mathrm{hES}$ cells and their derivatives may eventually contribute to clinical applications, the accurate determination of their differentiation state by qRT-PCR requires suitable reference genes. We have used two different hES cell lines, VUB01 and VUB02, to evaluate biological variation (Mateizel et al., 2005). Surprisingly, $18 \mathrm{~S}$ came out as one of the most stable reference genes, which is in contrast with mES cells and the mouse embryo where $18 \mathrm{~S}$ ranked poorly. Even though $18 \mathrm{~S}$ was reported more stable by others (Goidin et al., 2001; Tricarico et al., 2002), rRNA does not represent the mRNA and $\mathrm{RRNA}$ and mRNA fractions of the total RNA can vary from sample to sample (Solanas et al., 2001). Therefore UBC, PGK1 and GAPDH were selected as the most stable reference genes. It is also worth mentioning that ACTB, stable in the mouse system, is not stable in human, which is in agreement with previous studies (Goidin et al., 2001).

When considering both cell lines separately, PGK1 and TBP were ranked differently in both cell lines, suggesting that the expression of both genes might be variable between samples of different origin. Recent publications on transcriptome analysis of different hES cell lines show differences in expression of numerous genes including PGK1 (Richards et al., 2004; Zeng et al., 2004). Even though it is advised to study each cell line carefully and work with multiple reference genes, GAPDH was not variable between hES cell lines VUB01 and VUB02 and between different hES cell lines studied by others and could thus be suitable as a single reference gene when studying hES cells, but this approach is less reliable than the use of normalization factors based on several reference genes and should thus only be used with when practically more advantageous (Richards et al., 2004).

After differentiation of mES cells with DMSO and RA, Actb is among the most stable reference genes together with the sugar metabolism genes Gapdh and Pgk1. The stability of Gapdh and the instability of Hprt1 (located in the bottom of the ranking) were also found by Murphy and Polak (2002) in differentiating mES cells using classic RT-PCR. For spontaneous differentiation, the same reference genes were found to be stable, indicating that altering the direction of differentiation has no effect on the stability of the reference genes studied.

Neural induction with RA was used as a model to show the impact of using different reference genes by following the expression of Mash1 over time (Fig. 1). In the mouse embryo the expression of Mash1 was shown to start at $8.5 \mathrm{dpc}$ (in the developing nervous system) and to decrease after $12.5 \mathrm{dpc}$ (Guillemot and Joyner, 1993). After correction for the reference gene B2m, Mash1 is already highly expressed in EB from day four on, while when using Tbp (a relative stable reference gene) as a reference gene, Mash1 expression steadily increases up to fourteen days. With Actb correction, Mash 1 is only highly detected at day 8 , which relates to the results by Bain et al. using Northern blot on RA treated mES cells and correspond to the expression pattern and the biological role of Mash1 in the mouse embryo (Guillemot and Joyner, 1993; Bain et al., 1996). The latter techniques however are not always absolutely reliable since normal- 
ization is often inadequate and therefore one should be alert when comparing results from these techniques to qRT-PCR data. Nevertheless, this finding addresses that not only the stability of a reference gene, but also suggests that the experimental outcome after applying (a) reference gene(s) should be studied before being able to validate the reference gene(s).

The determination of stable reference genes is necessary in the developing mouse and in differentiating ES cells as they are complex systems that are closely related to each other and in which qRT-PCR is increasingly applied for comparative gene expression studies. Several important stages in the developing mouse were thus selected to represent the heterogeneity of the developing mouse system. Additionally, RNA from embryos from different litters was extracted and pooled to be able to compensate for biological diversity between embryos. In the mouse embryo, Tbp and Actb were found most stable. Even though ACTB has been described as unsuitable in several studies on other cell types or species (Schmittgen and Zakrajsek, 2000; de Kok et al., 2005), this stability may depend entirely on the experimental system. Moreover, the genes of sugar metabolism were found at the bottom of the ranking because they are downregulated in preimplantation development compared to postimplantation when corrected for the stable Actb (Fig. 2). Indeed, a switch from pyruvate to glucose metabolism occurs within the developing blastocyst as seen by the measurement of lactate production (Wales, 1986). On the contrary, the expression of Hprt1, another lowly ranked gene, was much higher in blastocysts compared to later developmental stages (Fig. 2), correlating with the high activity of Hprt1 in mouse blastocysts followed by a decrease in later developmental stages (Kratzer and Gartler, 1978). Hprt1 and genes of the glycolytic pathway are thus unsuitable when comparing mouse preimplantation and postimplantation development, since they show a high variation at those stages.

To illustrate the need for accurate relative quantification using suitable reference genes, the expression of Oct4 and Nanog was studied in mouse blastocysts and mES cells. It has been shown that tight control of Oct4 and possibly Nanog expression in mES cells is crucial, since overexpression or repression of both genes leads respectively to differentiation into mesoderm and endoderm or differentiation into trophectoderm (Niwa et al., 2000; Chambers et al., 2003). Table II illustrates that when using a less stable reference gene such as Gapdh or Hprt1, biased results are obtained. When a stable reference gene is used, for example Actb, the levels of Oct4 and Nanog are similar in blastocysts and mES cells. Even though, to our knowledge, no quantitative comparison of their expression levels between mES cells and the blastocyst has been published, both markers have been shown to be highly expressed in mES cells as well as is mouse blastocysts (Chambers et al., 2003). Based on these results, similar levels of Oct4 and Nanog were expected in blastocysts and mES cells as shown in Table II. Using an inappropriate reference gene in this case thus has a significant impact on data interpretation.

\section{What is the way to normalization?}

Even though multiple reference genes nowadays are the golden standard for normalization, a single reference gene (for example in mammalian development or ES cells) would facilitate research. Since single reference genes are still widely used and because it is often impractical to use multiple reference genes,
TABLE 3

\section{OVERALL RANKING OF THE GENES IN EACH OF THE SYSTEMS} TESTED IN THIS STUDY

\begin{tabular}{lcccccr} 
& \multicolumn{2}{c}{ Embryo } & \multicolumn{2}{c}{ mES } & \multicolumn{2}{c}{ hES } \\
OverallRanking & N & G & N & G & N & G \\
\hline GAPDH & 5 & 5 & 3 & 1 & 4 & 2 \\
TBP & 1 & 1 & 5 & 4 & 6 & 6 \\
ACTB & 3 & 2 & 1 & 2 & 9 & 9 \\
18S & 6 & 6 & 4 & 5 & 3 & 3 \\
PGK1 & 8 & 8 & 2 & 3 & 2 & 4 \\
G6PD & 2 & 3 & 6 & 6 & 5 & 5 \\
UBC & 4 & 4 & 8 & 9 & 1 & 1 \\
HPRT1 & 9 & 9 & 7 & 7 & 8 & 8 \\
LDHA & 10 & 10 & 9 & 8 & 7 & 7 \\
B2M & 7 & 7 & 10 & 10 & 10 & 10 \\
\hline
\end{tabular}

The results from both Normfinder $(\mathrm{N})$ and geNorm $(\mathrm{G})$ were combined to obtain an overview of stability ranking similarity of the reference genes studied in the following systems: mouse embryo (embryo), mES differentiation (mES) and hES differentiation (hES).

one reference gene might be sufficient as proposed recently (de Kok et al., 2005). Therefore, we have used our reference gene ranking results to identify suitable single reference genes, which could be useful in one or more of the systems analyzed. By thoroughly analyzing reference genes before use, it could be possible to only use one instead of multiple reference genes.

In Table III we give a combined overview of the reference gene ranking in each of the systems tested in this study. The results clearly illustrate that there is no consistency in ranking between the different systems, but in some combinations of two systems a single reference gene could be used. For example GAPDH appears to be the best gene in most systems: it performs well in mES as well as in hES cells, but it should not be used in mouse embryonic development. Similarly, ACTB can be used in studies of mouse embryos and mES cells, but it should not be used in hES cells.

However, we would like to point out that this approach is much less consistent than the use of multiple reference genes and therefore we advise to calculate normalization factors based on the three most stable reference genes in the ranking for each system.

In conclusion, we have tested and validated reference genes in the developing mouse embryo as well as in mouse and human ES cell differentiation. In addition, we show the importance of testing candidate reference genes in heterogeneous cell populations since the use of an inappropriate reference gene can have a substantial impact on the interpretation of an experiment. We would also like to emphasize, that the reference genes we have found to be stable should only be used in systems similar to the ones tested.

For the normalization of data of an experiment we advise to apply the use of normalization factors, which are based on several reference genes found in the top of the ranking. When practically impossible, the use of a single gene could be allowed but one should be aware of the lower reliability of the obtained results in comparison to the multiple reference gene approach.

\section{Materials and Methods}

\section{Sample preparation}

Mouse E14 ES cells were cultured on mitomycin C (Sigma, St Louis MO, USA) treated SNL76/7 fibroblasts in Knock Out DMEM (GIBCO, 
Carlsbad CA, USA) supplemented with $15 \%$ fetal calf serum (FCS) (Hyclone, Logan UT, USA), $0.1 \mathrm{mM}$ beta-mercaptoethanol (GIBCO), $1 \%$ non-essential amino acids (GIBCO), 2mM L-glutamine (Sigma), antibiotics (Sigma) and LIF conditioned medium (Smith, 1991).

Differentiation of mES cells in ES cell medium without LIF (differentiating medium) was induced by the formation of embryoid bodies (EB) with the hanging drop method using approximately 1000 ES cells per drop. After two days, EB were resuspended in differentiating medium and neuronal or cardiac development was induced by adding $10^{-6} \mathrm{M}$ RA (Sigma) or $1 \%$ DMSO (Sigma), respectively. After eight days, EB were plated on gelatinized dishes for six more days. Samples were collected at days $0,4,8$ and 14 .

Human ES cell lines VUB01 and VUB02 (Mateizel et al., 2005) were cultured on mitomycin $\mathrm{C}$ treated mouse embryonic fibroblasts in Knock Out DMEM (GIBCO) supplemented with 20\% Knock Out Serum Replacement (GIBCO), $2 \mathrm{mM} \mathrm{L-glutamine,} 1 \%$ non-essential amino acids, $0.1 \mathrm{mM}$ beta-mercaptoethanol and $4 \mathrm{ng} / \mathrm{ml}$ human recombinant basic Fibroblast Growth Factor (hrbFGF) (Invitrogen, Carlsbad CA, USA). Passaging was performed by either mechanical slicing of ES cell colonies using a blunt-edge pulled pipette or by using $1 \mathrm{mg} / \mathrm{ml}$ collagenase type IV (Invitrogen).

To induce EB formation, undifferentiated hES cell colonies were collected using collagenase type IV and transferred to non-adherent dishes. EB were cultured in hES medium without hrbFGF in the presence of $15 \%$ FCS and were trypsinized and plated onto gelatinized dishes at day twelve. Samples were collected at days 0, 6, 12 and 24 .

Embryos from pregnant CD1 females of three to six months old were collected at the indicated time points. Blastocysts were flushed from the oviduct before implantation and older embryos were dissected from the uterus. Animal research was carried out with the authorization of the ethics committee of the Vrije Universiteit Brussel.

\section{RNA extraction and reverse transcription}

Mouse embryos as well as human and mouse ES cell samples were collected in denaturing buffer from the corresponding RNA extraction kits and stored at $-20^{\circ} \mathrm{C}$ until RNA was isolated. All RNA samples from mES cell experiments were extracted using the RNagents kit (Promega, Madison WI, USA). For mouse embryos from different stages and the human ES cell samples, RNA was extracted using the RNeasy kit (Qiagen, Valencia CA, USA). A DNase treatment was performed on all samples. RNA quality was assessed by gel electrophoresis and was quantified using Ribogreen (Molecular Probes, Eugene OR, USA). To limit biological variation, multiple embryos from different females were pooled, independent experiments for ES cell differentiation were carried out and two different cell lines of hES cells were used.

Depending on the availability of RNA for each sample 50ng or 500ng of RNA was used for reverse transcription as previously described (Kemp et al., 2005) and the cDNA was diluted to 60 microliters with water.

\section{Quantitative PCR}

For gene expression analysis one microliter of CDNA was used in a SYBR Green real time PCR reaction. QPCR was performed with primer annealing at $58^{\circ} \mathrm{C}$ and fluorescence read after the extension step of $72^{\circ} \mathrm{C}$ on an iCycler IQ (Bio-Rad, Hercules CA, USA) using the No Rox qPCR core kit for SYBR Green (Eurogentec, Seraing, Belgium).

Primer sequences were obtained from the available databases, Primer Bank by Wang and Seed (2003) and Real Time Primer Database (RTPDB) by Pattyn et al. (2003), whenever available, otherwise primers were designed using Beacon Designer 3.0 (Premier Biosoft Intl, Palo Alto CA, USA). Primers were selected over intron-exon boundaries whenever possible to avoid genomic DNA amplification. After DNase treatment, little DNA contamination in -RT controls was present, appearing $>20$ cycles later than the $+R T$ samples, which also excludes the amplification of possible pseudogenes present in the genome. Primer details are available in Supplementary Table A. Selfdesigned primers are available in the RTPDB (http://medgen.ugent.be/ rtprimerdb/).

\section{Data processing}

Ct values were exported into Microsoft Excel from the iCycler IQ software. For the reference gene analysis tools, geNorm and Normfinder (Vandesompele et al., 2002; Andersen et al., 2004), Ct values were converted into quantities $(Q)$ corrected for PCR efficiency $(E)$ by the following formula:

$$
Q=(E)^{d C t}
$$

with $\mathrm{dCt}=\mathrm{Ct}$ of the highest abundant sample $-\mathrm{Ct}$ of the sample and $\mathrm{E}$ as determined by LinReg (Ramakers et al., 2003).

The quantities were then imported into both analysis tools, which were used as described in their manuals. For all reference genes studied, three independent data points were introduced in geNorm or Normfinder for every condition (time point) within each system (mES with RA or DMSO, $\mathrm{hES}$ or embryo). In the case of hES we have used three data points of each cell line (VUB001 and VUB002) for all time points. Both tools generate a value representing the stability of the gene. A low value corresponds to a stable gene whereas a higher value corresponds to a less stable gene. Stability values of both tools should not be compared as they are the result of two different mathematical approaches.

To calculate the relative expression $(R)$ of a gene of interest $(\mathrm{GOI})$ in a certain sample compared to a control sample, the formula described by Pfaffl (2001), which includes correction for the PCR efficiency (E) and a reference gene (REF), was used:

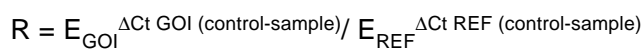

with control as the highest abundant sample in the experimental system.

\section{Acknowledgements}

We would like to thank $M$. Metioui for critically reading the manuscript. We would also like to acknowledge the financial support from the Vrije Universiteit Brussel (Horizontal Action) and the Belgian Science Policy (Attraction Pole 5/35).

\section{References}

ANDERSEN, C.L., JENSEN, J.L. and ORNTOFT, T.F. (2004). Normalization of real-time quantitative reverse transcription-pcr data: A model-based variance estimation approach to identify genes suited for normalization, applied to bladder and colon cancer data sets. Cancer Res 64: 5245-50.

BAIN, G., RAY, W.J., YAO, M. and GOTTLIEB, D.I. (1996). Retinoic acid promotes neural and represses mesodermal gene expression in mouse embryonic stem cells in culture. Biochem Biophys Res Commun 223: 691-4.

BUSTIN, S.A. (2002). Quantification of mrna using real-time reverse transcription pcr (rt-pcr): Trends and problems. JMol Endocrino/29: 23-39.

CHAMBERS, I., COLBY, D., ROBERTSON, M., NICHOLS, J., LEE, S., TWEEDIE, S. and SMITH, A. (2003). Functional expression cloning of nanog, a pluripotency sustaining factor in embryonic stem cells. Cel/113: 643-55.

DE KOK, J.B., ROELOFS, R.W., GIESENDORF, B.A., PENNINGS, J.L., WAAS, E.T., FEUTH, T., SWINKELS, D.W. and SPAN, P.N. (2005). Normalization of gene expression measurements in tumor tissues: Comparison of 13 endogenous control genes. Lab Invest 85: 154-9.

EVANS, M.J. and KAUFMAN, M.H. (1981). Establishment in culture of pluripotential cells from mouse embryos. Nature 292: 154-6.

FEHLING, H.J., LACAUD, G., KUBO, A., KENNEDY, M., ROBERTSON, S., KELLER, G. and KOUSKOFF, V. (2003). Tracking mesoderm induction and its specification to the hemangioblast during embryonic stem cell differentiation. Development 130: 4217-27.

GOIDIN, D., MAMESSIER, A., STAQUET, M.J., SCHMITT, D. and BERTHIER- 
VERGNES, O. (2001). Ribosomal 18s rna prevails over glyceraldehyde-3phosphate dehydrogenase and beta-actin genes as internal standard for quantitative comparison of mrna levels in invasive and noninvasive human melanoma cell subpopulations. Anal Biochem 295: 17-21.

GUILLEMOT, F. and JOYNER, A.L. (1993). Dynamic expression of the murine achaete-scute homologue mash-1 in the developing nervous system. Mech Dev 42: 171-85.

HASHIMOTO, J.G., BEADLES-BOHLING, A.S. and WIREN, K.M. (2004). Comparison of ribogreen and $18 \mathrm{~s}$ rrna quantitation for normalizing real-time rt-pcr expression analysis. Biotechniques 36: 54-6, 58-60.

HOERNDLI, F.J., TOIGO, M., SCHILD, A., GOTZ, J. and DAY, P.J. (2004). Reference genes identified in sh-sy5y cells using custom-made gene arrays with validation by quantitative polymerase chain reaction. Anal Biochem 335: 30-41.

KEMP, C., WILLEMS, E., ABDO, S., LAMBIV, L. and LEYNS, L. (2005). Expression of all wnt genes and their secreted antagonists during mouse blastocyst and postimplantation development. Dev Dyn 233: 1064-75.

KRATZER, P.G. and GARTLER, S.M. (1978). Hgprt activity changes in preimplantation mouse embryos. Nature 274: 503-4.

KUBO, A., SHINOZAKI, K., SHANNON, J.M., KOUSKOFF, V., KENNEDY, M., WOO, S., FEHLING, H.J. and KELLER, G. (2004). Development of definitive endoderm from embryonic stem cells in culture. Development 131: 1651-62.

MALTSEV, V.A., ROHWEDEL, J., HESCHELER, J. and WOBUS, A.M. (1993). Embryonic stem cells differentiate in vitro into cardiomyocytes representing sinusnodal, atrial and ventricular cell types. Mech Dev 44: 41-50.

MATEIZEL, I., DE TEMMERMAN, N., ULLMANN, U., CAUFFMAN, G., SERMON, K., VAN DE VELDE, H., DE RYCKE, M., DEGREEF, E., DEVROEY, P., LIEBAERS, I. et al. (2006). Derivation of human embryonic stem cell lines from embryos obtained after IVF and after pgd for monogenic disorders. Hum Reprod. 21: 503-511.

MURPHY, C.L. and POLAK, J.M. (2002). Differentiating embryonic stem cells: Gapdh, but neither hprt nor beta-tubulin is suitable as an internal standard for measuring rna levels. Tissue Eng 8: 551-9.

NIWA, H., MIYAZAKI, J. and SMITH, A.G. (2000). Quantitative expression of oct$3 / 4$ defines differentiation, dedifferentiation or self-renewal of es cells. Nat Genet 24: 372-6.

PATTYN, F., SPELEMAN, F., DE PAEPE, A. and VANDESOMPELE, J. (2003). Rtprimerdb: The real-time pcr primer and probe database. Nucleic Acids Res 31: 122-3.

PFAFFL, M.W. (2001). A new mathematical model for relative quantification in realtime rt-pcr. Nucleic Acids Res 29: e45.

PFAFFL, M.W., TICHOPAD, A., PRGOMET, C. and NEUVIANS, T.P. (2004). Determination of stable housekeeping genes, differentially regulated target genes and sample integrity: Bestkeeper excel-based tool using pair-wise correlations. Biotechnol Lett 26: 509-15.

RAMAKERS, C., RUIJTER, J.M., DEPREZ, R.H. and MOORMAN, A.F. (2003). Assumption-free analysis of quantitative real-time polymerase chain reaction (pcr) data. Neurosci Lett 339: 62-6.

RICHARDS, M., TAN, S.P., TAN, J.H., CHAN, W.K. and BONGSO, A. (2004). The transcriptome profile of human embryonic stem cells as defined by sage. Stem Cells 22: 51-64.
SCHMITTGEN, T.D. and ZAKRAJSEK, B.A. (2000). Effect of experimental treatment on housekeeping gene expression: Validation by real-time, quantitative rtpcr. J Biochem Biophys Methods 46: 69-81.

SCHULDINER, M., YANUKA, O., ITSKOVITZ-ELDOR, J., MELTON, D.A. and BENVENISTY, N. (2000). Effects of eight growth factors on the differentiation of cells derived from human embryonic stem cells. Proc Nat/ Acad Sci USA97: 11307-12.

SMITH, A.G. (1991). Culture and differentiation of embryonic stem cells. J Tiss Cult Meth 13: 89-94.

SMITH, A.G. (2001). Embryo-derived stem cells: Of mice and men. Annu Rev Cell Dev Bio/17: 435-62.

SOLANAS, M., MORAL, R. and ESCRICH, E. (2001). Unsuitability of using ribosomal rna as loading control for northern blot analyses related to the imbalance between messenger and ribosomal rna content in rat mammary tumors. Anal Biochem 288: 99-102.

STAHLBERG, A., HAKANSSON, J., XIAN, X., SEMB, H. and KUBISTA, M. (2004). Properties of the reverse transcription reaction in mrna quantification. Clin Chem 50: 509-15.

SZABO, A., PEROU, C.M., KARACA, M., PERREARD, L., QUACKENBUSH, J.F. and BERNARD, P.S. (2004). Statistical modeling for selecting housekeeper genes. Genome Bio/5: R59.

TADA, S., ERA, T., FURUSAWA, C., SAKURAI, H., NISHIKAWA, S., KINOSHITA, M., NAKAO, K. and CHIBA, T. (2005). Characterization of mesendoderm: A diverging point of the definitive endoderm and mesoderm in embryonic stem cell differentiation culture. Development 132: 4363-74.

THOMSON, J.A., ITSKOVITZ-ELDOR, J., SHAPIRO, S.S., WAKNITZ, M.A., SWIERGIEL, J.J., MARSHALL, V.S. and JONES, J.M. (1998). Embryonic stem cell lines derived from human blastocysts. Science 282: 1145-7.

TRICARICO, C., PINZANI, P., BIANCHI, S., PAGLIERANI, M., DISTANTE, V., PAZZAGLI, M., BUSTIN, S.A. and ORLANDO, C. (2002). Quantitative real-time reverse transcription polymerase chain reaction: Normalization to rrna or single housekeeping genes is inappropriate for human tissue biopsies. Anal Biochem 309: 293-300.

VANDESOMPELE, J., DE PRETER, K., PATTYN, F., POPPE, B., VAN ROY, N., DE PAEPE, A. and SPELEMAN, F. (2002). Accurate normalization of real-time quantitative rt-pcr data by geometric averaging of multiple internal control genes. Genome Bio/3: RESEARCH0034.

WALES, R.G. (1986). Measurement of metabolic turnover in single mouse embryos. J Reprod Fertil76: 717-25.

WANG, X. and SEED, B. (2003). A pcr primer bank for quantitative gene expression analysis. Nucleic Acids Res 31: e154.

ZENG, X., MIURA, T., LUO, Y., BHATTACHARYA, B., CONDIE, B., CHEN, J., GINIS, I., LYONS, I., MEJIDO, J., PURI, R.K. et al. (2004). Properties of pluripotent human embryonic stem cells bg01 and bg02. Stem Cells 22: 292312.

Received: November 2005 Reviewed by Referees: March 2006 Modified by Authors and Accepted for Publication: April 2006 Published Online: July 2006 


\title{
Supplementary Tables
}

\author{
SUPPLEMENTARY TABLE A
}

A

DETAILS OF PRIMERS USED

\begin{tabular}{|c|c|c|c|c|c|c|c|}
\hline $\begin{array}{l}\text { Gene } \\
\text { Symbol }\end{array}$ & $\begin{array}{l}\text { GenBank } \\
\text { Accession }\end{array}$ & $\begin{array}{l}\text { Primer } \\
\text { Position }\end{array}$ & Primer Sequence (5' to $\left.3^{\prime}\right)$ & $\begin{array}{l}\text { Ampli- } \\
\text { con (bp) }\end{array}$ & $\begin{array}{l}\text { Intron } \\
\text { Spanning }\end{array}$ & $\begin{array}{l}\text { Pseudo- } \\
\text { genes }\end{array}$ & Database \\
\hline $\begin{array}{l}18 S \\
\text { rRNA }\end{array}$ & X00686 & $\begin{array}{l}\mathrm{F} 1202 \\
\mathrm{R} 1331\end{array}$ & $\begin{array}{l}\text { TTGACGGAAGGGCACCACCAG } \\
\text { GCACCACCACCCACGGAATCG }\end{array}$ & 130 & $\begin{array}{l}\text { Intronless } \\
\text { gene }\end{array}$ & Yes & RTPDB \\
\hline Actb & NM_007393 & $\begin{array}{l}\text { F162 } \\
\text { R426 }\end{array}$ & $\begin{array}{l}\text { GCTGTATTCCCCTCCATCGTG } \\
\text { CACGGTTGGCCTTAGGGTTCAG }\end{array}$ & 265 & 87 bp & Yes & $\begin{array}{c}\text { Self } \\
\text { (ID3574) }\end{array}$ \\
\hline Gapdh & NM_008084 & $\begin{array}{l}\text { F705 } \\
\text { R788 }\end{array}$ & $\begin{array}{l}\text { CCCCAATGTGTCCGTCGTG } \\
\text { GCCTGCTTCACCACCTTCT }\end{array}$ & 84 & $\begin{array}{l}\text { Intronless } \\
\text { gene }\end{array}$ & Yes & $\begin{array}{l}\text { Self } \\
\text { (ID3575) }\end{array}$ \\
\hline G6pd & NM_019468 & $\begin{array}{l}\text { F485 } \\
\text { R669 }\end{array}$ & $\begin{array}{l}\text { CAGGCTTTAACCGCATCATAGT } \\
\text { AGGGCCAAAGATCCTGTTAGC }\end{array}$ & 185 & $\begin{array}{l}\text { Intronless } \\
\text { gene }\end{array}$ & No & PB \\
\hline Ldha & NM_010699 & $\begin{array}{l}\text { F231 } \\
\text { R385 }\end{array}$ & $\begin{array}{l}\text { TGTCTCCAGCAAAGACTACTGT } \\
\text { GACTGTACTTGACAATGTTGGGA }\end{array}$ & 155 & 1227 bp & Yes & PB \\
\hline Ubc & NM_019639 & $\begin{array}{l}\mathrm{F} 2581 \\
\mathrm{R} 2661\end{array}$ & $\begin{array}{l}\text { AGGTCAAACAGGAAGACAGACGTA } \\
\text { TCACACCCAAGAACAAGCACA }\end{array}$ & 80 & No & No & RTPDB \\
\hline Tbp & U63933 & $\begin{array}{l}\mathrm{F} 125 \\
\mathrm{R} 291\end{array}$ & $\begin{array}{l}\text { GGCCTCTCAGAAGCATCACTA } \\
\text { GCCAAGCCCTGAGCATAA }\end{array}$ & 166 & $1761 \mathrm{bp}$ & No & RTPDB \\
\hline B2m & NM_009735 & $\begin{array}{l}\text { F26 } \\
\text { R129 }\end{array}$ & $\begin{array}{l}\text { TTCTGGTGCCTTGTCTCACTGA } \\
\text { CAGTATGTTCGGCTTCCCATTC }\end{array}$ & 104 & 3068 bp & No & PB \\
\hline Hprt1 & NM_013556 & $\begin{array}{l}\text { F324 } \\
\text { R465 }\end{array}$ & $\begin{array}{l}\text { TCAGTCAACGGGGGACATAAA } \\
\text { GGGGCTGTACTGCTTAACCAG }\end{array}$ & 142 & 3898 bp & No & PB \\
\hline Pgk1 & NM_008828 & $\begin{array}{l}\text { F364 } \\
\text { R480 }\end{array}$ & $\begin{array}{l}\text { CTCCGCTTTCATGTAGAGGAAG } \\
\text { GACATCTCCTAGTTTGGACAGTG }\end{array}$ & 117 & $\begin{array}{l}\text { Intronless } \\
\text { gene }\end{array}$ & Yes & PB \\
\hline Nanog & AB093574 & $\begin{array}{l}\text { F558 } \\
\text { R658 }\end{array}$ & $\begin{array}{l}\text { CCTCAGCСTCCAGCAGATGC } \\
\text { CCGCTTGCACTTCACССTTTG }\end{array}$ & 100 & $821 \mathrm{bp}$ & Yes & $\begin{array}{c}\text { Self } \\
\text { (ID3576) }\end{array}$ \\
\hline Pou5f1 & NM_013633 & $\begin{array}{l}\mathrm{F} 487 \\
\mathrm{R} 615\end{array}$ & $\begin{array}{l}\text { GAAGCAGAAGAGGATCACCTTG } \\
\text { TTCTTAAGGCTGAGCTGCAAG }\end{array}$ & 128 & $185 \mathrm{bp}$ & Yes & $\begin{array}{c}\text { Self } \\
\text { (ID3577) }\end{array}$ \\
\hline
\end{tabular}

B

\begin{tabular}{|c|c|c|c|c|c|c|c|}
\hline $\begin{array}{l}\text { Gene } \\
\text { Symbol }\end{array}$ & $\begin{array}{c}\text { GenBank } \\
\text { Accession }\end{array}$ & $\begin{array}{l}\text { Primer } \\
\text { Position }\end{array}$ & Primer Sequence $\left(5^{\prime}\right.$ to $\left.3^{\prime}\right)$ & $\begin{array}{l}\text { Ampli- } \\
\text { con (bp) }\end{array}$ & $\begin{array}{l}\text { Intron } \\
\text { Spanning }\end{array}$ & $\begin{array}{l}\text { Pseudo- } \\
\text { genes }\end{array}$ & Database \\
\hline $\begin{array}{l}18 S \\
\text { rRNA }\end{array}$ & X03205 & $\begin{array}{l}\mathrm{F} 1275 \\
\mathrm{R} 1397\end{array}$ & $\begin{array}{l}\text { GACACGGACAGGATTGACAGATTG } \\
\text { TGCCAGAGTCTCGTTCGTTATCG }\end{array}$ & 122 & $\begin{array}{l}\text { Intronless } \\
\text { gene }\end{array}$ & Yes & $\begin{array}{c}\text { Self } \\
(\text { ID N/A) }\end{array}$ \\
\hline ACTB & NM_001101 & $\begin{array}{l}\text { F336 } \\
\text { R494 }\end{array}$ & $\begin{array}{l}\text { CACCTTCTACAATGAGCTGCGTGTG } \\
\text { ATAGCACAGCCTGGATAGCAACGTAC }\end{array}$ & 158 & 441 bp & Yes & RTPDB \\
\hline GAPDH & NM_002046 & $\begin{array}{l}\text { F528 } \\
\text { R614 }\end{array}$ & $\begin{array}{l}\text { TGCACCACCAACTGCTTAGC } \\
\text { GGCATGGACTGTGGTCATGAG }\end{array}$ & 86 & $193 \mathrm{bp}$ & Yes & RTPDB \\
\hline G6PD & NM_000402 & $\begin{array}{l}\text { F897 } \\
\text { R973 }\end{array}$ & $\begin{array}{l}\text { TGCCCCCGACCGTCTAC } \\
\text { ATGCGGTTCCAGCCTACTCTG }\end{array}$ & 76 & $671 \mathrm{bp}$ & No & RTPDB \\
\hline LDHA & NM_005566 & $\begin{array}{l}\text { F908 } \\
\text { R984 }\end{array}$ & $\begin{array}{l}\text { ACCCAGTTTCCACCATGATT } \\
\text { CCCAAAATGCAAGGAACACT }\end{array}$ & 76 & 1544 bp & Yes & RTPDB \\
\hline UBC & NM_021009 & $\begin{array}{l}\text { F19 } \\
\text { R152 }\end{array}$ & $\begin{array}{l}\text { ATTTGGGTCGCGGTTCTTG } \\
\text { TGCCTTGACATTCTCGATGGT }\end{array}$ & 133 & $812 b p$ & No & RTPDB \\
\hline TBP & NM_003194 & $\begin{array}{c}\text { F802 } \\
\text { R1028 }\end{array}$ & $\begin{array}{l}\text { GAATATAATCCCAAGCGGTTTG } \\
\text { ACTTCACACACAGCTCCCC }\end{array}$ & 226 & 4887 bp & No & RTPDB \\
\hline B2M & NM_004048 & $\begin{array}{l}\text { F330 } \\
\text { R598 }\end{array}$ & $\begin{array}{l}\text { ACCCCCACTGAAAAAGATGA } \\
\text { CTCAGATACATCAAACATGG }\end{array}$ & 268 & 1877 bp & No & RTPDB \\
\hline HPRT1 & NM_000194 & $\begin{array}{l}\text { F495 } \\
\text { R588 }\end{array}$ & $\begin{array}{l}\text { TGACACTGGCAAAACAATGCA } \\
\text { GGTCCTTTTCACCAGCAAGCT }\end{array}$ & 93 & 4799 bp & No & RTPDB \\
\hline PGK1 & NM_000291 & $\begin{array}{l}\text { F1134 } \\
\text { R1252 }\end{array}$ & $\begin{array}{l}\text { ATGGATGAGGTGGTGGAAAGC } \\
\text { CAGTGCTCACATGGCTGACT }\end{array}$ & 118 & 275 bp & Yes & RTPDB \\
\hline NANOG & NM_024865 & $\begin{array}{l}\text { F569 } \\
\text { R716 }\end{array}$ & $\begin{array}{l}\text { AATACCTCAGCCTCCAGCAGATG } \\
\text { TGCGTCACACCATTGCTATTCTTC }\end{array}$ & 148 & 1244 bp & Yes & $\begin{array}{c}\text { Self } \\
\text { (ID 3578) }\end{array}$ \\
\hline POU5F1 & NM_002701 & $\begin{array}{l}\text { F768 } \\
\text { R933 }\end{array}$ & $\begin{array}{l}\text { GAGAACCGAGTGAGAGGCAACC } \\
\text { CATAGTCGCTGCTTGATCGCTTG }\end{array}$ & 166 & $260 \mathrm{bp}$ & Yes & $\begin{array}{c}\text { Self } \\
\text { (ID 3579) }\end{array}$ \\
\hline
\end{tabular}

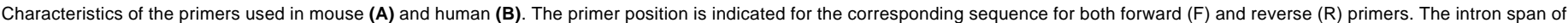

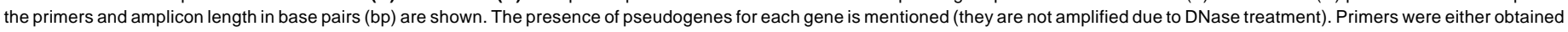
from RTPrimerDB (RTPDB) and PrimerBank (PB) or were self designed with Beacon Designer 3.0 (Self) and are available from RTPrimerDB (database ID is indicated). 
SUPPLEMENTARY TABLE B

\section{RANKING OF THE TEN REFERENCE GENES IN ES CELLS AND EMBRYO}

\begin{tabular}{|c|c|c|c|c|c|c|c|c|c|}
\hline A & \multicolumn{4}{|c|}{ Mouse Embryo } & C & \multicolumn{4}{|c|}{ mES/RA: Neuronal Differentiation } \\
\hline Rank & $\begin{array}{c}\text { Normfinder } \\
\text { Gene }\end{array}$ & Stability & $\begin{array}{c}\text { geNorm } \\
\text { Gene }\end{array}$ & Stability & Rank & $\begin{array}{c}\text { Normfinder } \\
\text { Gene }\end{array}$ & Stability & $\begin{array}{c}\text { geNorm } \\
\text { Gene }\end{array}$ & Stability \\
\hline 1 & Tbp & 0.17 & Tbp & 1.20 & 1 & Actb & 0.32 & Actb & 1.04 \\
\hline 2 & G6pd & 0.26 & Actb & 1.30 & 2 & Pgk1 & 0.41 & Pgk1 & 1.05 \\
\hline 3 & Actb & 0.28 & G6pd & 1.33 & 3 & Gapdh & 0.46 & Gapdh & 1.07 \\
\hline 4 & Ubc & 0.36 & Ubc & 1.33 & 4 & $18 \mathrm{~S}$ & 0.50 & Tbp & 1.14 \\
\hline 5 & Gapdh & 0.49 & Gapdh & 1.46 & 5 & Tbp & 0.53 & $18 \mathrm{~S}$ & 1.15 \\
\hline 6 & $18 \mathrm{~S}$ & 0.71 & $18 \mathrm{~S}$ & 1.53 & 6 & G6pd & 0.58 & G6pd & 1.19 \\
\hline 7 & $\mathrm{~B} 2 \mathrm{~m}$ & 0.84 & B2m & 1.65 & 7 & Hprt1 & 0.65 & Hprt1 & 1.26 \\
\hline 8 & Pgk1 & 0.84 & Pgk1 & 1.73 & 8 & Ubc & 0.67 & Ldha & 1.28 \\
\hline 9 & Hprt1 & 1.60 & Hprt1 & 2.46 & 9 & Ldha & 0.69 & Ubc & 1.30 \\
\hline 10 & Ldha & 2.02 & Ldha & 2.98 & 10 & $\mathrm{~B} 2 \mathrm{~m}$ & 1.11 & $\mathrm{~B} 2 \mathrm{~m}$ & 1.77 \\
\hline B & \multicolumn{4}{|c|}{$\underline{\text { mES/DMSO: Mesodermal Differentiation }}$} & D & \multicolumn{4}{|c|}{ HES: Spontaneous Differentiation } \\
\hline Rank & $\begin{array}{c}\text { Normfinder } \\
\text { Gene }\end{array}$ & Stability & $\begin{array}{c}\text { geNorm } \\
\text { Gene }\end{array}$ & Stability & Rank & $\begin{array}{c}\text { Normfinder } \\
\text { Gene }\end{array}$ & Stability & $\begin{array}{c}\text { geNorm } \\
\text { Gene }\end{array}$ & Stability \\
\hline 1 & Gapdh & 0.31 & Gapdh & 0.90 & 1 & UBC & 0.18 & UBC & 0.63 \\
\hline 2 & Actb & 0.33 & Tbp & 0.96 & 2 & PGK1 & 0.20 & GAPDH & 0.63 \\
\hline 3 & Pgk1 & 0.39 & Pgk1 & 0.97 & 3 & $18 \mathrm{~S}$ & 0.21 & $18 \mathrm{~S}$ & 0.63 \\
\hline 4 & Tbp & 0.40 & Actb & 1.00 & 4 & GAPDH & 0.21 & PGK1 & 0.65 \\
\hline 5 & $18 \mathrm{~S}$ & 0.44 & $18 \mathrm{~S}$ & 1.05 & 5 & G6PD & 0.31 & G6PD & 0.70 \\
\hline 6 & G6pd & 0.55 & G6pd & 1.09 & 6 & TBP & 0.39 & TBP & 0.78 \\
\hline 7 & Ldha & 0.60 & Ldha & 1.15 & 7 & LDHA & 0.44 & LDHA & 0.82 \\
\hline 8 & Hprt1 & 0.60 & Hprt1 & 1.16 & 8 & HPRT1 & 0.50 & HPRT1 & 0.88 \\
\hline 9 & Ubc & 0.69 & Ubc & 1.28 & 9 & ACTB & 0.54 & АСТВ & 0.95 \\
\hline 10 & B2m & 1.18 & B2m & 1.82 & 10 & $\mathrm{~B} 2 \mathrm{M}$ & 0.67 & $\mathrm{~B} 2 \mathrm{M}$ & 1.08 \\
\hline
\end{tabular}

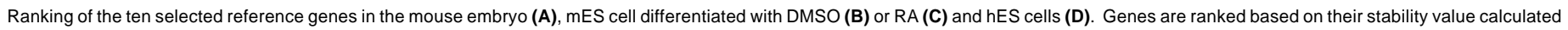
by Normfinder or geNorm. Stability values are given to illustrate the ranking (the lowest value corresponds to most stable and the highest value corresponds to least stable) 